\title{
RESPONSES IN THE DIET COMPOSITION OF THE COMMON FROG (RANA TEMPORARIA) TO THE STOCHASTIC GRADATION OF AUTUMNAL MOTH (EPIRRITA AUTUMNATA) LARVAE
}

\author{
Tibor Kovács ${ }^{1}$, Gábor Herczeg ${ }^{1}$ and Attila Hettyey ${ }^{2}$ \\ ${ }^{1}$ Behavioural Ecology Group, Department of Systematic Zoology and Ecology \\ Eötvös Loránd University, H-1117 Budapest, Pázmány Péter s. 1/c, Hungary \\ E-mails: gurgulo@gmail.com,gaborherczeg@caesar.elte.hu \\ ${ }^{2}$ Lendület Evolutionary Ecology Research Group, Plant Protection Institute, Centre for \\ Agricultural Research, Hungarian Academy of Sciences, \\ H-1022 Budapest, Herman Ottó út 15, Hungary; E-mail: hettyey.attila@agrar.mta.hu
}

We studied the feeding ecology of the common frog Rana temporaria in a population located at the subarctic taiga-tundra frontier in Finland over two consecutive years $(2002,2003)$. In the summer of 2003, an unexpected gradation of autumnal moth (Epirrita autumnata) larvae occurred at our study site. This situation allowed us to study the changes in the diet composition of the same common frog population between a presumably average and an extraordinary year with respect to the gradation of one of the prey species. We found clear evidence for the opportunistic feeding behaviour of common frogs in a natural population, as reflected by the mass appearance of Epirrita autumnata larvae in the frogs' stomach content in 2003. Further, our results draw attention to the fact that a one-year study on the feeding ecology of an opportunistic species can result in flawed conclusions.

Key words: opportunistic feeding behaviour, Anura, Finnish Lappland.

\section{INTRODUCTION}

To place a species on the continuum between the two extremes of specialist and generalist feeders, one has to compare its diet composition with the potential prey supply. This is often problematic, due to difficulties in the assessment of the latter (CoRnish et al. 1995), but has been attempted by a number of studies (e.g. Hirai \& Matsui 2001, Navarrete \& Manzur 2008, Bishop et al. 2014, Bower et al. 2014, Gye 2015, Reboucas \& Sole 2015). Selective choice vs. opportunistic behaviour in terms of readily accepting changes in the composition of potential prey is another important aspect of the feeding ecology of predators, which may be detected by repeated sampling from consecutive seasons or years. Many anurans are considered to be generalist and opportunist feeders consuming a wide variety of prey, mainly invertebrates, without detectable selection (Wells 2007, Huскемвеск 2014, Sснацк et al. 2014). A seasonal shift in diet composition is detected in several frog species and is frequently interpreted as the manifestation of opportunistic feeding behaviour (Kovács et al. 2007, Valderrana-Vernaza et al. 2009). However, we know of no field reports on the dietary response of amphibians to extreme 
changes in the relative abundance of potential prey types, for instance during the stochastic mass appearance of one potential prey species, i.e. gradation.

The common frog, Rana temporaria Linnaeus, 1758 is a widely distributed anuran occurring in mediterranean to subarctic climate zones of Eurasia (GASC et al. 1997). According to Terhivuo (1993) it is present throughout Finland but is less abundant at higher latitudes. Nevertheless, records are known even from around $70^{\circ}$ northern latitude. It has been proposed to be a generalist predator consuming a wide array of invertebrates (IтÄImes \& KosKela 1970, Blackith \& Speight 1974, Loman 1979, Meharg et al. 1990, Beebee \& Griffiths 2000, Stojanova \& Mollov 2008, Hodisan et al. 2010). Although $R$. temporaria is routinely labelled as a generalist and opportunistic forager, we are not aware of any field studies or manipulative experiments actually testing these statements.

Epirrita autumnata Borkhausen, 1794, a geometrid moth, has infrequent gradations (Начкіоја et al. 1988, Rчономёкі et al. 2001). In the vicinity of Kilpisjärvi (Finland), a dramatic gradation event happened in the year 2003. According to ANTERo Järvinen (pers. comm.), the staff of Kilpisjärvi Biological Station had not observed such an extreme gradation for at least three decades in retrospect. In the present note, we compare the diet composition of a Subarctic common frog population between two consecutive years $(2002,2003)$, with emphasis on the Epirrita autumnata gradation in 2003. The situation represented a "natural experiment" allowing us to test for the hypothesised generalist and opportunistic feeding strategy of common frogs living under challenging environmental conditions (viz. extreme short activity season, see Fig. 1 in HJERNQUIST et al. 2012). We predicted that the diet composition will show (i) high diversity in 2002 (sign of generalist strategy) and (ii) extremely low diversity, mainly consisting of Epirrita autumnata larvae, in 2003 (sign of opportunism).

\section{MATERIAL AND METHODS}

We visited the sampling site close to Kilpisjärvi $\left(69.0242^{\circ} \mathrm{N}, 20.8793^{\circ} \mathrm{E}\right)$, Northern Finland, to collect stomach contents from $R$. temporaria between 7-25 June 2002 and 3-8 July 2003. According to birch leafing data, both sampling periods fell into the middle of the activity season of the respective year. Birch leafing (bl) may be used in subarctic ecological studies in Finland as an indicator of the timing of spring/summer transition (JÄrvINEN 1989). The summer of 2002 started early (bl: 31st May) and it was about average in 2003 (bl: 17th June). Hence, we assumed that our samplings in the consecutive years represent the same withinyear period. The sampling site was a shallow pond lying at the southern foot of Hill Saana, on the border of birch (Betula pubescens cherepanovii) forest and open tundra vegetation.

We obtained stomach contents from 47 adult individuals in 2002 and from 17 in 2003. We did not distinguish between males and females. We hand-collected frogs and used the standard stomach-flushing method of Legler and Sullivan (1979) to gain information about stomach contents. The first specimens of E. autumnata larvae were identified by local experts of Kilpisjärvi Biological Station, and since there are no similar species in the area, 
we carried out the identification from the rest of the stomach contents. Prey items were identified to order level because identification on the species level requires special expert assistance and it was not necessary for the purpose of the present study. Hymenopterans were divided into two groups; ants and wasps or bees.

We calculated diet diversity using the Shannon-Weaver formula

$$
H^{\prime}=-\sum_{i=1}^{s} p_{i} * \ln \left(p_{i}\right)
$$

where $p_{\mathrm{i}}$ is the proportion of prey type $i$ in the total sample. We compared diversity indices using the Hutcheson t-test (HuTCHESON 1970). The similarity between diet compositions was estimated with the Proportional Similarity Index, PSI $=\sum \min \left(p_{\mathrm{x}, \mathrm{i}} p_{\mathrm{y}, \mathrm{i}}\right)$, where $p_{\mathrm{x}, \mathrm{i}}$ is the proportion of prey type $i$ in sample $\mathrm{x}$ and where $p_{\mathrm{y}, \mathrm{i}}$ is the proportion of prey type $i$ in sample y. To verify our sample sizes for the determination of variation in diet composition we applied rarefaction analysis (KovÁcs \& Тӧвӧк 1997). To give a sound estimate of diet diversity, one has to make sure that the sample size (i.e. the number of sampled individuals) is large enough to avoid the underestimation of the true diet diversity. Rarefaction is a calculation technique which allows for the estimation of species diversity from individual samples by creating rarefaction curves. Rarefaction curves are built up of a series of diversity values randomly re-sampled from the original pool of $N$ samples. The calculation results in an average diversity value for each set of $n$ sample obtained from a larger pool of $N$ samples.

\section{RESULTS}

The rarefaction analyses on the diet diversity resulted in quickly saturating curves in both years (Fig. 1) reaching the maximal value of 1.92 in 2002 and 0.66 in 2003. Minimal sample sizes were calculated as the sample size needed for the $95 \%$ of the estimated maximal diet diversity. Our sample sizes appeared adequate to describe the actual diet diversity: the minimal sample sizes were estimated as $\mathrm{N}=16$ for 2002 (we sampled 47 frogs) and $\mathrm{N}=5$ for 2003 (we sampled 17 frogs) (for more details about the method see Kovács \& TöRöк 1997).

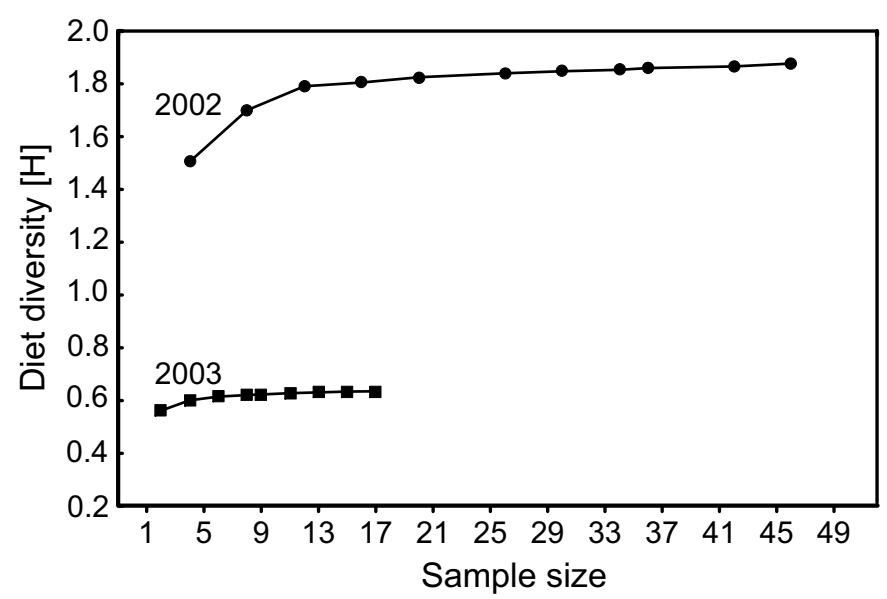

Fig. 1. Saturation curves of rarefaction analyses of the diet compositions of Rana temporaria 
The difference between the diet diversities estimated in the two consecutive years was highly significant $\left(t_{343}=10.55, P<0.001\right)$. The diet composition of frogs collected in 2002 mainly consisted of dipterans, coleopterans, gastropods and arachnids (Fig. 2). These four taxa formed more than $80 \%$ of the consumed prey. Other taxa representing more than one individual, such as hymenopterans (including formicids), homopterans, heteropterans, lepidopteran larvae, were represented by less than $14 \%$ all together. The majority of the obtained food consisted of terrestrial invertebrates; the only typical aquatic prey we found was the pond skater (Gerris sp., 2.4\%). In 2003, lepidopteran larvae belonging to one species (E. autumnata), became the dominant food item as their proportion approached $90 \%$ (Fig. 2).

The frogs consumed mainly ground-dwelling prey items (65.2 and $97.2 \%$ of their diet, respectively for 2002 and 2003), however, the similarity between the two years was extremely low $(\mathrm{PSI}=0.16)$.

\section{DISCUSSION}

According to our results from 2002, subarctic common frogs consume a wide variety of invertebrate taxa. Their diet composition does not qualitatively differ from what was found typical for populations in southern Sweden (Loman 1979), Northern Ireland (Meharg et al. 1989), Ukraine (Kuzmin 1990), Poland (Stojanova \& Mollov 2008) and Romania (Hodisan et al. 2010). ItÄImes and Koskela (1970) collected data on the diet composition of R. temporaria in Northern Finland. The four most numerous prey groups in their

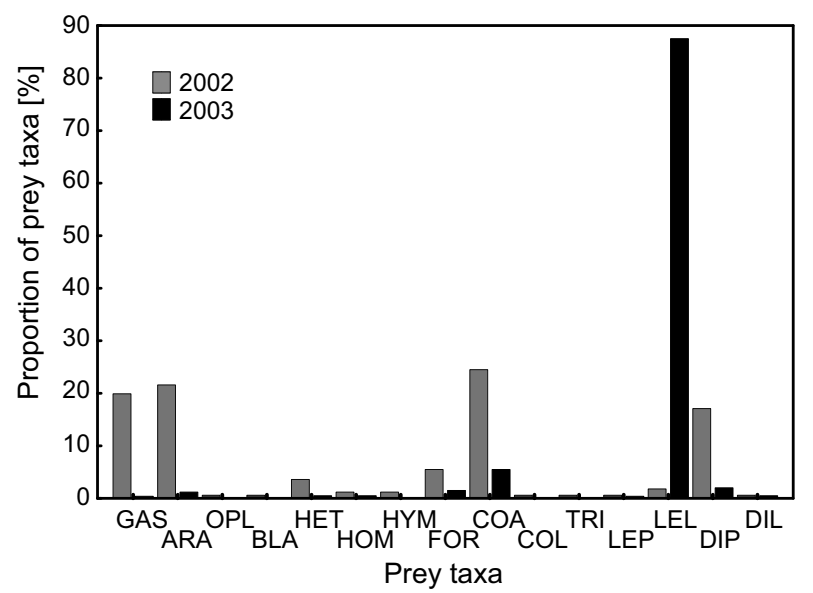

Fig. 2. Diet compositions of Rana temporaria in two consecutive years. Abbreviations: GAS: Gastropoda, ARA: Arachnida, OPL: Phalangidea, BLA: Blattidea, HET: Heteroptera, HOM: Homoptera, HYM: Hymenoptera (without ants), FOR: Formicidea, COA: Coleoptera, COL: Coleoptera larvae, TRI: Trichoptera, LEP: Lepidoptera, LEL: Lepidoptera larvae, DIP: Diptera, DIL: Diptera larvae 
study (gastropods, dipterans, coleopterans and arachnids) were identical to those in our samples from 2002. Therefore, it is fair to assume that our 2002 sample represented an 'average' year regarding diet availability/composition. Besides reinforcing the classification of $R$. temporaria as a generalist predator based on our data obtained in 2002, we found clear evidence for its opportunistic feeding strategy as reflected by the mass appearance of the larvae of $E$. autumnata in its diet in the extraordinary year of 2003.

In spite of the stereotypic picture that anurans are generalist and opportunistic predators (WELLS 2007) the feeding habits of several amphibian species show a more diverse picture. Mite and ant eating is common amongst tropical poison frog species (Woodhead et al. 2007, SABAGH et al. 2012). Mite eating is also known in specialized foreger salamander Salamandrina perspicillata (Costa et al. 2015). Boelter et al. (2012) proved that invasive Lithobates catesbeianus consume other frog species selectively and in high volume. In a study on a Hungarian frog assemblage Kovács (2003) found that Bombina bombina tend to eat a vast amount of collembolas from the water surface while adult Bufo bufo tend to prey on ants primarily in the same location. However, $R$. temporaria from our population, representing the northernmost anuran occurrence (e.g. Gasc et al. 1997), can be classified as a generalist opportunistic predator with enough flexibility to switch almost entirely to a prey item that has negligible contribution to the food of the population in an 'average' year and to that of other studied populations too (ITÄImes \& Koskela 1970, LoMAN 1979). Living at such high latitude poses severe challenges to anurans. The activity period in the studied population is approximately. three months per year (LAugen et al. 2003, HJernouist et al. 2012). R. temporaria at this latitude grow very slowly while showing extreme longevity with delayed maturation (HJERnquist et al. 2012). Slow growth must be a combined result of the short activity season (short time window to acquire energy for growth, overwintering and reproduction) and the increased need for energy storage important to buffer against climatic stochasticity (JöNsson et al. 2009). These energetic constraints are strong enough to negatively affect reproductive investments, which are of central importance in increasing individual fitness (HETTYEY et al. 2005). Such extreme energy constraints will force frogs to utilize any possible prey item they encounter, and thus indeed pose strong selection for a generalist opportunistic foraging strategy, especially because densities of many potential prey species tend to decrease towards high latitudes (BRown 1984, Barrios-Garcia et al. 2015, Kozlov et al. 2015).

Taken together, by accidentally sampling $R$. temporaria diet in the extraordinary year of 2003 when a rare mass gradation of E. autumnata larvae occurred, we could prove the opportunistic feeding strategy of $R$. temporaria. This emphasizes the benefit of monitoring in years / seasons / periods when stochastic events lead to marked environmental deviations from the long- 
term norm, turning monitoring studies into natural experiments that cannot be planned. However, it also stresses a potential bias inherent to short-term monitoring studies. When an animal species is selected for long term monitoring for conservation purposes, the disclosure of its feeding ecology can be a crucial element of the project (Kovács et al. 2007, Costa et al. 2015, Liess 2015). Our results clearly show that a one-year study on the feeding ecology of an opportunistic species might be highly misleading if the sampling year is extraordinary in the composition of food supply. This conclusion should be taken into account when a poorly studied species is monitored in order to gain reliable information on its ecological relationships.

Acknowledgement - We are thankful to A. Järvinen and J. Merilä who helped us find a suitable location, to O. Järvinen for her keen help in the field and to B. Anthony for correcting the English. We would like to express our in memoriam acknowledgement to T. Hampori for her contribution to the logistics part of our study. The research was funded by the EU 'LAPBIAT' project (no. HPRI-CT-2001-00132). GH received financial support from the Hungarian Scientific Research Fund (OTKA \# K105517) and was supported by the János Bólyai Research Scholarship of the Hungarian Academy of Sciences.

\section{REFERENCES}

Barrios-Garcia, M. A., Rodriguez-Cabal, M. A., González, A. L. \& Crutsinger, G. M. (2015): Biogeographical variation in arthropod communities on coyote bush, Baccharis pilularis. Insect Conservation and Diversity 8: 81-91. https://doi.org/10.1111/icad.12086

Beebee, T. \& Griffith, R. (2000): Amphibians and Reptiles - A Natural History of British Herpetofauna. Harper Collins Publishers, London, 270 pp.

Bishop, M. R., Drewes, R. C \& Vredenburg, V. T. (2014): Food web linkages demonstrate importance of terrestrial prey for the threatened california red-legged frog. Journal of Herpetology 48: 137-143. https://doi.org/10.1670/12-288

Blackith, R. M. \& Speight, M. C. D. (1974): Food and feeding habits of the frog Rana temporaria in bogland habitats in the West of Ireland. Journal of Zoology, London 172: 67-79. https://doi.org/10.1111/j.1469-7998.1974.tb04094.x

Boelter, R. A., Kaefer, I. L., Both, C. \& Cechin, S. (2012): Invasive bullfrogs as predators in a Neotropical assemblage: What frog species do they eat? Animal Biology 62: 397-408. https://doi.org/10.1163/157075612X634111

Bower, D. S., Pickett, E. J \& Garnham, J. I. (2014): Diet of a threatened pond frog differs over a small spatial scale. Endangered Species Research 23: 93-98. https://doi. org/10.3354/esr00559

Brown, J. H. (1984): On the relationship between abundance and distribution of species. The American Naturalist 124(2): 225-279. https://doi.org/10.1086/284267

Cornish, C. A., Oldham, R. S., Bullock, D. J. \& Bullock, J. A. (1995): Comparison of the diet of adult toads (Bufo bufo L.) with pitfall trap catches. Herpetological Journal 5: 236-238.

Costa, A., Salvidio, S., Posillico, M., Matteucci, G., De Cinti, B. \& Romano, A. (2015): Generalisation within specialization: inter-individual diet variation in the only spe- 
cialized salamander in the world. Scientific Reports 5: 13260. https://doi.org/10.1038/ srep13260

Gasc, J.-P., Cabela, A., Crnobrnja-Isailovic, J., Dolmen, D., Grossenbacher, K., Haffner, P., Lescure, J., Martens, H., Martinéz, Rica, J. P., Oliveira, M. E., Sofianidou, T. S., Veith, M. \& Zuiderwijk, A. (eds) (1997): Atlas of amphibians and reptiles of Europe. Societas Europaea Herpetologica and Muséum National d'Histoire, Paris, 494 pp.

Gre, M. Сн. (2015): Diet of the Korean Wrinkled Frog (Rana rugosa). Korean Journal of Environmental Biology 33(3): 338-344. https://doi.org/10.11626/KJEB.2015.33.3.338

Haukioja, E., Neuvone, S., Hanhimäki, S. \& Niemelä, P. (1988): The autumnal moth in Fennoscandia. Pp. 164-179. In: Berryman, A. A. (ed.): Dynamics of forest insect populations. Plenum, New York. https://doi.org/10.1007/978-1-4899-0789-9_9

Hettyey, A., Laurila, A., Herczeg, G., Jönsson, K. I., Kovács, T. \& Merilä, J. (2005): Does testis weight decline towards the Subarctic? A case study on the common frog, Rana temporaria. Naturwissenschaften 92:188-192. https://doi.org/10.1007/s00114-005-0607-3

Hirai, T. \& Matsui, M. (2001): Food of an endangered Japanese frog, Rana porosa brevipoda. Ecological Research 16: 737-743. https://doi.org/10.1046/j.1440-1703.2001.00430.x

Hjernquist, M. B., Söderman, F., Jönsson, K. I., Herczeg, G., Laurila, A. \& Merilä, J. (2012): Seasonality determines patterns of growth and age structure over a geographic gradient in an ectothermic vertebrate. Oecologia 170: 641-649. https://doi. org/10.1007/s00442-012-2338-4

Hodisan, O. I., Benchiş, A., Gabrian, D., Badar, L. \& Toader, S. (2010): The trophic spectrum of two brown frog populations (Rana dalmatina and Rana temporaria) from Baia de Fier area, Romania. Herpetologica Romanica 4: 7-16.

Huckembeck, S., Loebmann, D. \& Albertoni, E. F. (2014): Feeding ecology and basal food sources that sustain the Paradoxal frog Pseudis minuta: a multiple approach combining stomach content, prey availability, and stable isotopes. Hydrobiologia 740(1): 253-264. https://doi.org/10.1007/s10750-014-2022-2

Hutcheson, K. (1970): A test for comparing diversities based on the Shannon formula. Journal of Theoretical Biology 29: 151-154. https://doi.org/10.1016/0022-5193(70)90124-4

ItÄimes, J. \& Koskela, P. (1970): On the diet of the common frog (Rana temporaria L.). Aquilo Series Zoologica 10: 53-60.

Järvinen, A. (1989): Patterns and causes of long-term variation in reproductive traits of the Pied Flycatcher Ficedula hypoleuca in Finnish Lapland. Ornis Fennica 66: 24-31.

Jönsson, K. I., Herczeg, G., O’Hara, R. B., Söderman, F., Shureter, A. F. H., Larsson, P. \& Merilä, J. (2009): Sexual patterns of prebreeding energy reserves of common frog Rana temporaria along a latitudinal gradient. Ecography 32: 831-839. https://doi. org/10.1111/j.1600-0587.2009.05352.x

Kovács, É. H., SAs, I. \& Covaciu-Marcov, S-D. (2007): Seasonal variation in the diet of a population of Hyla arborea from Romania. Amphibia-Reptilia 28: 485-491. https://doi. org/10.1163/156853807782152534

KovÁcs, T. \& Töвöк, J. (1997): Determination of minimum sample size to estimate diet diversity in anuran species. Herpetological Journal 7: 43-47.

Kovács, T. (2003): Faunistic survey and ecology of the amphibians (Amphibia) of Kis-Balaton. Doctoral thesis, Eötvös Loránd University, Budapest, 118 pp.

Kozlov, M. V., Stańska, M., Hajdamowicz, I., Zverev, V. \& Zvereva, E. L. (2015): Factors shaping latitudinal patterns in communities of arboreal spiders in northern Europe. Ecography 38(10): 1026-1035. https://doi.org/10.1111/ecog.01401

Kuzmin, S. L. (1990): Trophic niche overlap in syntopic postmetamorphic amphibians of the Carpathian Mountains (Ukraine: Soviet Union). Herpetozoa 3(1-2): 13-24. 
Laugen, A. T., Laurila, A., Räsänen, K. \& Merilä, J. (2003): Latitudinal countergradient variation in the common frog (Rana temporaria) development rates - evidence for local adaptation. Journal of Evolutionary Biology 16: 996-1005. https://doi.org/10.1046/ j.1420-9101.2003.00560.x

Legler, J. M. \& Sullivan, L. J. (1979): The application of stomach-flushing to lizards and anurans. Herpetologica 35: 107-110.

Liess, A., Guo, J. W., Lind, M. I. \& Rowe, O. (2015): Cool tadpoles from Arctic environments waste fewer nutrients - high gross growth efficiencies lead to low consumer-mediated nutrient recycling in the North. Journal of Animal Ecology 84(6): 1744-1756. https:// doi.org/10.1111/1365-2656.12426

Loman, J. (1979): Food, feeding rates and prey size selection in juvenile and adult frogs, Rana arvalis and Rana temporaria. Ekologia Polska 27(4): 581-601.

Meharg, M. J., Montgomery, W. I. \& Dunwoody, M. (1990): Trophic relationship of common frog (Rana temporaria) and pigmy shrew (Sorex minutus) in upland Co Antrim, Northern Ireland. Journal of Zoology 222: 1-17. https://doi.org/10.1111/j.1469-7998.1990. tb04025.x

Navarrete, S. A. \& Manzur, T. (2008): Individual- and population-level responses of a keystone predator to geographic variation in prey. Ecology 89: 2005-2018. https://doi. org/10.1890/07-1231.1

Reboucas, R. \& Sole, M. (2015): Diet of Adenomera thomei (Almeida and Angulo, 2006) (Anura: Leptodactylidae) from a rubber tree plantation in southern Bahia, Brazil. Studies on Neotropical Fauna and Environment 50(2): 73-79. http://dx.doi.org/10.1080/0 1650521.2015.1048613

Ruohomäкi, K., Tanhuanpä̈̈, M., Ayres, M. P., Kaitaniemi, P., Tammaru, T. \& HaukioJA, E. (2001): Causes of cyclicity of Epirrita autumnata (Lepidoptera, Geometridae) - grandiose theory and tedious practice. Population Ecology 42: 211-223. https://doi. org/10.1007/PL00012000

Sabagh, L. T., Mello, R. S. \& Rocha, C. F. D. (2012): Food niche overlap between two sympatric leaf-litter frog species from Central Amazonia. Zoologia (Curitiba) 29: 95-98. https://doi.org/10.1590/S1984-46702012000100013

Schalk, C. M., Montana, C. G. \& Klemish, J. L. (2014): On the diet of the frogs of the Ceratophryidae: Synopsis and new contributions. South American Journal of Herpetology 9(2): 90-105. https://doi.org/10.2994/SAJH-D-14-00008.1

Stojanova, A. M. \& Mollov, I. A. (2008): Diet and trophic niche overlap of the Moor Frog (Rana arvalis Nilsson, 1842) and the Common Frog (Rana temporaria L., 1758) from Poland. Proceedings of the Anniversary Scientific Conference of Ecology, Plovdiv, pp. 181-190.

Terhivuo, J. (1993): Provisional atlas and status of populations for the herpetofauna of Finland in 1980-1992. Annales Zoologici Fennici 30: 55-69.

Valderrana-Vernaza, M., Ramirez-Pinilla, M. P \& Serrano-Cardozo, V. H. (2009): Diet of the Andean Frog Ranitomeya virolinensis (Athesphatanura: Dendrobatidae). Journal of Herpetology 43(1): 114-123. https://doi.org/10.1670/07-247R1.1

Wells, K. D. (2007): The ecology and behaviour of amphibians. University of Chicago Press, Chicago, 1148 pp. https://doi.org/10.7208/chicago/9780226893334.001.0001

Woodhead, C., Vences, M., Vieites, D. R., Gamboni, I., Fisher, B. L. \& Griffiths, R. A. (2007): Specialist or generalist?: Feeding ecology of the Malagasy poison frog Mantella aurantiaca. Herpetological Journal 17(4): 225-236.

Received September 1, 2016, accepted July 20, 2016, published March 3, 2017 